\title{
IMPACT OF IT AN INNOVATION ON BUSINESS EDUCATION
}

\author{
Dr. Mirza Viquar Ahmed \\ Assistant Professor, Business Administration Department, \\ Jubail University College, PO. Box 10074, Jubail Industrial City 31961 \\ Kingdom of Saudi Arabia
}

\begin{abstract}
The aim of this paper is to provide the knowledge related to the impact of information technology an innovation on business education. This paper will discuss what the necessary skills are needed to be successful in business. In addition, it will also discuss the use of info graphics in order to enhance the knowledge area of its users. The Information Technology (IT) and the Information and Communication Technology (ICT) are integrating and innovating the relationship between the organizations and individuals.
\end{abstract}

Keywords: Information and communication technology (ICT), E-commerce, info graphics, innovation in business, B2C

Cite this Article: Dr. Mirza Viquar Ahmed, Impact of IT an Innovation on Business Education, International Journal of Management, 10 (5), 2019, pp. 109-114.

http://iaeme.com/Home/issue/IJM?Volume $=10 \&$ Issue $=5$

\section{INTRODUCTION}

This is a crucial fact of twenty first century that information technology has been enabling the transformation of world into a global village frequently. Transference of information and confidential data to any location throughout the world is quite easy with the advent of information technology. There are numerous communication tools such as personal computers, laptops, smart phones and tablets that are the fundamental source to conduct business [1]. Information technology is opening new vistas for business by providing advancement to the users in order to meet the challenges and demands of market.

Information technology is also providing new tools and facilities to the entrepreneurs to start and develop business. It has been observed that marketing, communication and business accounting have been enhancing by usage of communication and network technologies. The internet is a dynamic source to initiate a business as it provides a platform to compete with the large enterprises by using cost effective marketing and finance strategies in order to fulfill the demands of external and internal customers and to expand the number of customers.

\section{DISCUSSION}

When information technology is considered in the field of business, it comes in a picture that with the help of information technology, businesses are getting success and becoming 
progressive by leaps and bounds in this digital age. Business environment is rapidly transforming and becoming turbulent and chaotic for last few years. In order to survive in such a speedy thrive, an organization needs to be developed innovative ways to run the business [5, 7]. When it comes to provide best facilities and opportunities to the employees there is need of organizational climate or in simple words it can be said that the work environment matters to get maximum productivity by utilizing small span of time. Business leaders are using IT innovative environment in order to cope up the challenges and to bring the innovation and advancement in their business. Innovation has great impact on success of business as revolution brings progress in industries. In this modern digital age, it is hard to imagine to run a business without digital revolution.

\subsection{The Information Technology (IT) and Information and Communication Technology (ICT)}

The information technology (IT) and Information and Communication Technology (ICT) are used most of the time synonymously. There are four various approaches for IT and ICT in business education that are often utilized simultaneously Such as:

- IT and ICT are used as a mean of channel for assessment.

- IT and ICT are used as workshops for candidates and teachers.

- IT and ICT are used for delivering instruction

- IT and ICT are used to store information and for doing research as well $[4,6]$.

Technology and business transformation programs are going on national and international levels. These programs have goal to identify, associate and train those students who are passionate to gain maximum benefits by the latest information technologies. Furthermore, those students who want to bring digital innovation and transformation of business by participating in experiential and innovative learning.

\subsection{Use of Info Graphics}

Application of info graphics are developing the suite of competencies in the emerging global economy. Here some uses of info graphics are discussed below:

\subsubsection{Catching the Attention of Audience}

This is a natural fact that human beings are visual creatures and most of the time, they are attracted visually. It has been observed that more than $90 \%$ information comes into the mind is required active optic nerve cells. Hence if your words are not enough to express your thoughts and fail to catch the imagination and attention of your audience then info graphics can be used for this purpose efficiently $[2,4]$. Therefore info graphics are consider crucial element in order to catch the attention of audience. Combining text and graphics allow communicators to deal with each strength and weakness of medium. Human beings naturally like facts, figures, graphics and other texts elements and if all these present enough in front of audience, so info graphics can easily captured their attention with in blink of an eye.

\subsubsection{Increase Brand Awareness}

Info graphics help to increase your brand awareness as they are designed to have appropriate information of the creators such as website, logo, email, address and contact information as well.

Rather than telling the people about your brand, products and services, info graphics show them in visual content with efficient way that increase the brand awareness and attract the attention of people. 


\subsubsection{Increment in Search Market Results}

Info graphics help to boost the market search rankings. As far as info graphics consider viral, the most beneficial impact is known in market searching results. It is not only created for limited contacts and sharing but it also develops significant backlinks of online channels. Most of the users like to contact with your business when they see your images in an info graphic relevant source as per their needs.

\subsubsection{Increase in Subscribers and Followers}

The visual content has an immense power to increase the followers and subscribers on social media pages. Well-created and animated info graphics develop more comments, likes and sharing than any other text updating. It enhances more audiences as more as it is shared. Ultimately, it opens the gate to interact and engage with the audience and people become more aware of your products, services and brands and then they become paying customer eventually [2].

\subsubsection{Easily Embeddable and Portable}

This is one of the biggest characteristics of info graphics that as a visual element, info graphics are handy, portable and embeddable easily. They are designed in such a way that they have small graphics, short and understandable texts that represent the importance of confidential information [3]. This characteristic is appreciated among non-English global users who understand the things with the help of graphics, pictures rather than texts.

\subsubsection{Understandable Content}

As elaborate in above section that assigning of piece of information through easily comprehensible information represents the info graphics as a powerful visual tool. It has been observed that detailed and clear images attract the attention of more than $67 \%$ of customers [5, 6]. Similarly, people do not show interest in getting long text information rather they are interested in visual elements and graphics respectively.

\subsubsection{Beyond Digital Marketing}

The visual format of info graphics make it popular as much as it goes beyond digital marketing. It is easily applicable to print materials, offline tools and brochures as well. This characteristic of info graphic helps to generate revenue in new business [5].

\subsection{Role of Information Technology in Business}

Application of information technology in the field of business to bring innovation and success includes:

- Cyber security

- Fraud detection

- Social media

- Marketing intelligence

- Health care information systems

- Cloud computing

- Data analysis and report making

- Business intelligence

As innovation in information technology is a fundamental key to drive business growth and progress. Innovation develops the new ways to overcome the problems and complexities in difficult times. It enforces the people to think dramatically and doing the things in an improved way to meet the new strategies of business. The pathway of innovation leads towards new opportunities and doing the things smartly and in positive way in terms of quality, quantity, 
value, productivity, efficiency and proficiency. The wave of information technology has brought a change in the lives of an individual and organizations. In addition, social networking, real time monitoring, accurate business planning, digital communication, systematic management, effective marketing, project management and global sales are not possible without the information technology at the optimum level.

\subsection{Some Factors to Success in Business}

The success and progress of every business depend on some crucial factors. Some factors are: selection of appropriate technology, right decision at right time, customers support and satisfaction, resource management, accurate analysis and future vision are highly appreciable.

\subsubsection{Decision Making}

Every organization has to make right decision with accuracy and proficiency for progress in business. A comprehensive market research makes it easy to take right decision at right time [4]. Tools of information technology including Microsoft CRM Dynamic, Google Analytics are useful for decision making. These online tools also reduce the risks of human error.

\subsubsection{Marketing and Business Growth}

Marketing has an immense important to run the business just like the heart has immense importance in a body to function properly. Basically marketing enables the executive management to classify audience demands and targets and then detect their needs and trends. The whole marketing impacts on promotion, public relation, advertisement and sales which ultimately influence on growth of business. There are many types of marketing that enable the business growth but digital marketing is playing an essential part for rapid growth that is not possible without information technology. [2, 5]

Digital marketing is one of the modern techniques that helps to promote your products and services throughout the whole globe. This is quite a broad technique which comprises on Pay per Click (PPC), Search Engine Optimization (SEO), SMS, social media marketing, discussion forum, MMS, blogging, email shot and smartphone app advertisement. Nowadays, Web marketing is progressing frequently in this digital age because entrepreneurs and executive managements have understood that long term progress and success is not possible in business without the digital applications.

\subsubsection{Customer Satisfaction and Support}

The higher level of customer satisfaction is a crucial key for long term success in a business that is impossible without the support of customer in real time. Success of business depends on following factors such as knowing customers trends, needs, satisfaction level and behaviors. Effective communication is one of the key to know the customer demands, needs and trends. Bundle of thanks to information technology that enables the organizations to communicate effectively with the billions of customers throughout the world $[1,3]$

\subsubsection{E-commerce and B2C}

Skilled professional and expertise are using E-commerce and Business to Consumer (B2C) frequently in order to gain maximum productivity in their businesses. Therefore traditional markets and other marketplace has been narrow down with the passage of time. E-services are playing a vital role to manage the customer and executive relationship and to enhance the sales and productivity [3].Customers appreciate the e-services as they get their desire services and support at the time of their needs. 


\section{CONCLUSION}

From above discussion it has been concluded that the key formula for success in a business is to drive innovation and information technology simultaneously. It is not possible to attain long term success in a business without employing the advantages of information technology in this digital age. In addition, small and large enterprises have to endure a reasonable cost in order to bring innovation in business strategies.

Highly skilled employees, trained IT professional, project management, time management and right decision at right time are the recipe for the successful business. Innovated solutions and advancement in IT increase the efficiency, productivity effectiveness and proficiency of business and communication as well. Today, every organization, small or large enterprises are being enabled to develop innovation through information technology including financial services, marketing approaches, business accounting and health care settings respectively.

\section{REFERENCES}

[1] Chen, H., Chiang, R. H., \& Storey, V. C. 2012. Business intelligence and analytics: From big data to big impact. MIS quarterly, 36(4), 2012, pp 1165-1188.

[2] Drnevich, P. L., \& Croson, D. C, Information technology and business-level strategy: Toward an integrated theoretical perspective. Mis Quarterly, 37(2), 2013, pp 483-509.

[3] Edwards, R., Raggatt, P., \& Small, N. (Eds.), the learning society: challenges and trends. Routledge, 2013.

[4] Ellen, W., \& Stéphan, V. L, Educational research and innovation art for art's sake? The impact of arts education: The Impact of Arts Education. OECD Publishing, 2013.

[5] Lu, Y., \& K. (Ram) Ramamurthy, Understanding the link between information technology capability and organizational agility: An empirical examination. Mis Quarterly, pp 931954.

[6] Schwalbe, K, Information technology project management. Cengage Learning. Data retrieved from $\mathrm{http}: / / \mathrm{s} 3$.amazonaws.com/academia.edu.documents/46169145/5e-ch1.pdf?AWSAccessKeyId=AKIAIWOWYYGZ2Y53UL3A\&Expires=1491810747\&Signa

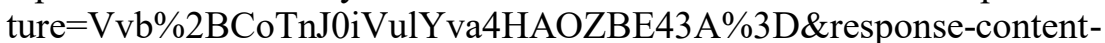
disposition=inline $\% 3 \mathrm{~B} \% 20$ filename\%3DAn_Introduction_to_Project_Management_Fi.pd f on 10th April, 2017,2015

[7] Willcocks, L, Information management: the evaluation of information systems investments. Springer, 2013.

[8] Sambit Kumar Hazra and Durga Shankar Rath, Factors Affecting Information and Communication Technology (ICT) Adoption in The University Libraries In West Bengal (India). Journal of Management, 5(3), 2018, pp. 216-225.

[9] X. Mercy Angeline, Impact of Information and Communication Technology on Information Needs and Information Seeking Behavior of Users of Arts and Science College Libraries In Trichy District: A Study. International Journal of Library \& Information Science, 6(6), 2017, pp. 75-81. 
Impact of IT an Innovation on Business Education

[10] Ebong, Mercy D. and Nelson, Etido E., Re-Engineering Cataloguing Services for Effective Library Operations in Information and Communication Technology (ICT) Era: A Case Analysis of University of UYO Library, Akwa Ibom State. International Journal of Library \& Information Science, 7(4), 2018, pp. 10-20. 